\title{
Awareness, Attitude and Knowledge of Emergency Management of Avulsed Tooth in Urban India
}

\author{
Dr. Sumita A. Bhagwat, Dr. Akshay Parmar, Dr. Lalitagauri P. Mandke
}

\begin{abstract}
Aims and Objective: Dental avulsion is the complete and total displacement of tooth from its socket. An avulsed tooth can possibly be re-implanted. There is a need to spread awareness amongst the population who are unaware of such treatment modalities. The present study aimed at investigating knowledge, attitude and awareness amongst population in Navi Mumbai about emergency management of avulsed tooth. An additional aim was to spread the correct knowledge and emergency protocol to be followed in case of dental avulsion. Materials and Methods: A contact survey was conducted with a sample size of 504 patients in the Department of Conservative Dentistry and Endodontics, D.Y Patil University, School of Dentistry, Navi Mumbai regarding their knowledge and awareness about emergency treatment of avulsed over a period of 3 months. Data was tabulated in excel sheet and analyzed using SPSS 22.0 software. Discussion and Conclusion: Patients themselves can play an important role in improving the prognosis of the avulsed tooth. Majority of the respondents (95\%) were unaware of possibility of re-implantation of avulsed tooth. Almost 88\% of female respondent disagreed to self re-implant the avulsed tooth. Majority of males and females said they would visit a dentist for emergency treatment. When asked about the cleaning media to be used to clean the dirty avulsed tooth, $36 \%$ of the illiterate respondents preferred to use a toothbrush. About $18 \%$ respondents chose ice water as storage medium to carry the avulsed tooth. Irrespective of education level, gender or awareness level of possibility of re-implantation of avulsed tooth, there is a general lack of awareness about the emergency management of avulsed tooth.
\end{abstract}

Keywords: Avulsion, Emergency treatment, Tooth re-implantation, Survey

\section{Introduction}

Traumatic injuries during childhood are quite common. Dental avulsion has an incidence of $0.5-3 \%$ of all traumatic injuries in permanent dentition and $7-13 \%$ in primary dentition. ${ }^{[1-4]}$ Studies have shown that about $50 \%$ of children have their primary or permanent dentition affected by traumatic injuries during their school life ${ }^{[1]}$. Teeth more commonly involved are the maxillary central and lateral incisors. Loss of the maxillary central/ lateral incisors can cause psychological, social, functional and aesthetic repercussion to the patient and thus effect overall growth as a person. It is very important for general population to understand the importance of saving the avulsed tooth and know the emergency management, if situation prevails.

Dental avulsion is defined as the complete and total displacement of tooth from its socket ${ }^{[8]}$. Prognosis of the tooth depends on the viability of the periodontal ligament and time elapsed since the incident took place. Studies done in the past have shown that there is a need to increase the awareness and spread the right knowledge amongst people about tooth avulsion ${ }^{[9-13]}$. This study was aimed at investigating the knowledge and awareness amongst population of a metropolitan city in western part of India about emergency management of avulsed tooth. An additional aim was to spread the correct knowledge and emergency protocol to be followed in case of dental avulsion.

\section{Materials and Method}

A randomized study with a sample size of 504 patients was conducted in Department of Conservative Dentistry and Endodontics over a period of 3 months. Ethical clearance was obtained from the institutional ethical committee. A questionnaire ( Table 1) was formulated to study the awareness and knowledge amongst general population regarding avulsed permanent teeth. A contact survey was carried out in English/Hindi/Marathi where the investigator was always present to assist the individuals who wished to be a part of this study. Every individual who participated in the survey signed an informed consent form. At the end of the questionnaire, the participants were told the right answers and were educated about the correct protocol to manage dental avulsion in future. Data was collected and tabulated in excel sheet and analysed using IPSS 22.0 software and a comparison was made based on level of education, gender and awareness of possible re-implantation following dental avulsion.

\section{Results}

Table 2 gives the demographic tabulation of the data. Tables 3 to 24 give the frequency dustribution of the responses to the questions in the survey and their statistical analysis.

Table 1: Questionnaire

\begin{tabular}{|c|c|}
\hline Questions & Options \\
\hline \multirow{2}{*}{$\begin{array}{l}\text { Are you aware of possibility of re- } \\
\text { implantation of avulsed tooth as part of } \\
\text { first-aid in treatment modality? }\end{array}$} & Yes \\
\hline & No \\
\hline \multirow{6}{*}{$\begin{array}{c}\text { How soon do you believe re- } \\
\text { implantation of avulsed tooth should be } \\
\text { done? }\end{array}$} & Immediately \\
\hline & As bleeding stops \\
\hline & After 1 hour \\
\hline & The same day \\
\hline & After few days \\
\hline & Later dental visits \\
\hline \multirow{2}{*}{$\begin{array}{l}\text { Would you attempt to self re-implant } \\
\text { the tooth? }\end{array}$} & Yes \\
\hline & No \\
\hline \multirow{4}{*}{$\begin{array}{l}\text { Who would you consult in case of an } \\
\text { avulsed tooth? }\end{array}$} & Doctor \\
\hline & $\begin{array}{c}\text { Family member/ Friend/ } \\
\text { Neighbour }\end{array}$ \\
\hline & Dentist \\
\hline & Other \\
\hline \multirow{2}{*}{$\begin{array}{l}\text { Are you aware that you have to clean } \\
\text { the dirty avulsed tooth? }\end{array}$} & Yes \\
\hline & No \\
\hline
\end{tabular}




\section{International Journal of Science and Research (IJSR) \\ ISSN (Online): 2319-7064}

Index Copernicus Value (2013): 6.14 | Impact Factor (2014): 5.611

\begin{tabular}{|c|c|}
\hline How would you clean the dirty avulsed & Milk \\
\cline { 2 - 2 } tooth? & Brush \\
\cline { 2 - 2 } & Salt water \\
\cline { 2 - 2 } & Water \\
\hline How would you carry the tooth? & Nothing \\
\cline { 2 - 2 } & Wrap the tooth in paper/ \\
handkerchief
\end{tabular}

Table 2: Demographic data

\begin{tabular}{|l|r|r|}
\hline Variables & Frequency & Percent \\
\hline Total Respondents & 504 & 100 \\
\hline GENDER & 322 & 63.9 \\
\hline Male & 182 & 36.1 \\
\hline Female & \multicolumn{2}{|l}{} \\
\hline EDUCATION & 140 & 27.8 \\
\hline Elementary School & 96 & 19 \\
\hline Graduate & 225 & 44.7 \\
\hline Higher Secondary School & 28 & 5.5 \\
\hline Non-Literate & 15 & 3 \\
\hline Postgraduate &
\end{tabular}

Table 3: Frequency distribution of responses for Q.1 Are you aware of possibility of re-implantation of avulsed tooth as part of first-aid in treatment modality?

\begin{tabular}{|c|c|c|c|c|c|}
\hline \multicolumn{2}{|c|}{} & Frequency & Percent & Valid Percent & $\begin{array}{c}\text { Cumulative } \\
\text { Percent }\end{array}$ \\
\hline \multirow{3}{*}{ Valid } & No & 479 & 95 & 95 & 95 \\
\cline { 2 - 6 } & Yes & 25 & 5 & 5 & 100 \\
\cline { 2 - 6 } & Total & 504 & 100 & 100 & \\
\hline
\end{tabular}

Table 4: Comparison of awareness of possibility of re-implantation of avulsed tooth as part of first-aid in treatment modality and Education and Gender:

\begin{tabular}{|c|c|c|c|c|c|}
\hline \multicolumn{6}{|c|}{ Custom Table } \\
\hline & & \multicolumn{4}{|c|}{ Are you aware of possibility of re-implantation of avulsed tooth as part of first-aid in treatment modality? } \\
\hline & & \multicolumn{2}{|c|}{ Yes } & \multicolumn{2}{|c|}{ No } \\
\hline & & Count & Column N \% & Count & Column N \% \\
\hline \multirow[t]{5}{*}{ Education } & Illiterate & 2 & $8.70 \%$ & 26 & $5.60 \%$ \\
\hline & Elementary school & 5 & $21.70 \%$ & 135 & $29.00 \%$ \\
\hline & Higher secondary & 9 & $39.10 \%$ & 216 & $46.40 \%$ \\
\hline & Graduate & 7 & $30.40 \%$ & 89 & $19.10 \%$ \\
\hline & Post graduate & 0 & $0.00 \%$ & 0 & $0.00 \%$ \\
\hline \multirow[t]{2}{*}{ Gender } & Male & 16 & $61.50 \%$ & 306 & $64.00 \%$ \\
\hline & Female & 10 & $38.50 \%$ & 172 & $36.00 \%$ \\
\hline
\end{tabular}

Chi-square value:

\begin{tabular}{|c|c|c|}
\hline \multicolumn{3}{|c|}{ Pearson Chi-Square Tests } \\
\hline \multirow{3}{*}{ Education } & Chi-square & Value \\
\cline { 2 - 3 } & $\mathrm{df}$ & 2.455 \\
\cline { 2 - 3 } & $\mathrm{p}$-value & 3 \\
\hline \multirow{2}{*}{ Gender } & Chi-square & 0.483 \\
\cline { 2 - 3 } & $\mathrm{Df}$ & 0.066 \\
\cline { 2 - 3 } & $\mathrm{p}-$-value & 0.798 \\
\hline Results are based on nonempty rows and columns in each innermost \\
\end{tabular}

\section{****p-value less than $\mathbf{0 . 0 5}$ indicates significant association.}

Interpretation: Since p-value for the chi-square is greater than that of 0.05 indicates no association of education,

Table 6: Comparison of belief of promptness of re-implantation of avulsed tooth and Education
Gender and Awareness. So we can conclude that the awareness is independent of Education and Gender.

Table 5: Frequency distribution of responses for Q.2 How soon do you believe re-implantation of avulsed tooth should be done?

\begin{tabular}{|c|c|c|c|c|c|}
\hline \multicolumn{2}{|c|}{} & Frequency & Percent & $\begin{array}{c}\text { Valid } \\
\text { Percent }\end{array}$ & $\begin{array}{c}\text { Cumulative } \\
\text { Percent }\end{array}$ \\
\hline Valid & After 1 hour & 20 & 4.0 & 4.0 & 4.0 \\
\cline { 2 - 6 } & After few days & 13 & 2.6 & 2.6 & 6.5 \\
\cline { 2 - 6 } & As bleeding stops & 172 & 34.1 & 34.1 & 40.7 \\
\hline & Immediately & 244 & 48.4 & 48.4 & 89.1 \\
\hline Later dental visit & 22 & 4.4 & 4.4 & 93.5 \\
\hline & The same day & 33 & 6.5 & 6.5 & 100.0 \\
\hline & Total & 504 & 100.0 & 100.0 & \\
\hline
\end{tabular}




\section{International Journal of Science and Research (IJSR) \\ ISSN (Online): 2319-7064}

Index Copernicus Value (2013): 6.14 | Impact Factor (2014): 5.611

\begin{tabular}{|c|c|c|c|c|c|c|c|}
\hline & & \multicolumn{6}{|c|}{ How soon do you believe re-implantation of avulsed tooth should be done? } \\
\hline Education & & Immediately & As bleeding stops & Later dental visit & After 1 hour & The same day & After few days \\
\hline \multirow{2}{*}{ Illiterate } & Count & 8 & 7 & 4 & 0 & 5 & 4 \\
\hline & $\%$ & $28.60 \%$ & $25.00 \%$ & $14.30 \%$ & $0.00 \%$ & $17.90 \%$ & $14.30 \%$ \\
\hline \multirow{2}{*}{$\begin{array}{c}\text { Elementary } \\
\text { school }\end{array}$} & Count & 53 & 50 & 12 & 6 & 12 & 7 \\
\hline & $\%$ & $37.90 \%$ & $35.70 \%$ & $8.60 \%$ & $4.30 \%$ & $8.60 \%$ & $5.00 \%$ \\
\hline \multirow{2}{*}{$\begin{array}{c}\text { Higher } \\
\text { secondary }\end{array}$} & Count & 110 & 81 & 4 & 11 & 14 & 2 \\
\hline & $\%$ & $49.50 \%$ & $36.50 \%$ & $1.80 \%$ & $5.00 \%$ & $6.30 \%$ & $0.90 \%$ \\
\hline \multirow{2}{*}{ Graduate } & Count & 58 & 31 & 2 & 3 & 2 & 0 \\
\hline & $\%$ & $60.40 \%$ & $32.30 \%$ & $2.10 \%$ & $3.10 \%$ & $2.10 \%$ & $0.00 \%$ \\
\hline \multirow{2}{*}{ Post graduate } & Count & 0 & 0 & 0 & 0 & 0 & 0 \\
\hline & $\%$ & $0.00 \%$ & $0.00 \%$ & $0.00 \%$ & $0.00 \%$ & $0.00 \%$ & $0.00 \%$ \\
\hline \multicolumn{2}{|c|}{ Chi-square test value } & \multicolumn{6}{|c|}{58.3} \\
\hline \multicolumn{2}{|c|}{$\mathrm{Df}$} & \multicolumn{6}{|c|}{15} \\
\hline \multicolumn{2}{|c|}{ p-value } & \multicolumn{6}{|c|}{0.000} \\
\hline
\end{tabular}

$* * * * p$-value less than 0.05 indicates significant association.

Interpretation: Since p-value for the chi-square is less than that of 0.05 indicates significant association with education.

Table 7: Frequency distribution of responses for Q.3 Would you attempt to self re-implant the tooth?

\begin{tabular}{|c|c|c|c|c|c|}
\hline \multicolumn{2}{|c|}{} & Frequency & Percent & $\begin{array}{c}\text { Valid } \\
\text { Percent }\end{array}$ & $\begin{array}{c}\text { Cumulative } \\
\text { Percent }\end{array}$ \\
\hline \multirow{3}{*}{ Valid } & No & 410 & 81.3 & 81.3 & 81.3 \\
\cline { 2 - 6 } & Yes & 94 & 18.7 & 18.7 & 100.0 \\
\cline { 2 - 6 } & Total & 504 & 100.0 & 100.0 & \\
\hline
\end{tabular}

Table 8: Comparison of attempt to self re-implant the tooth and Education

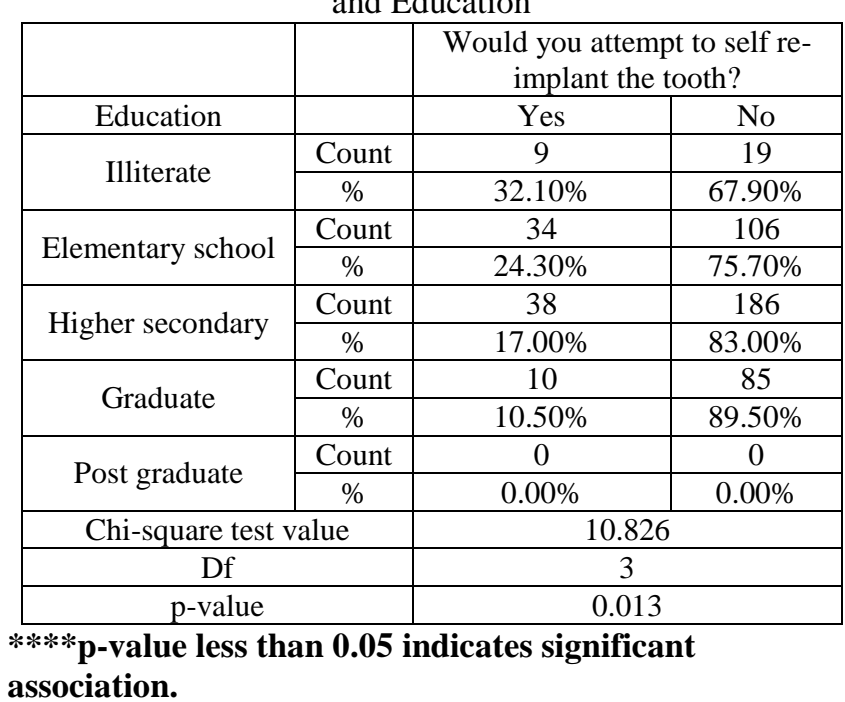

Interpretation: Since p-value for the chi-square is less than that of 0.05 indicates significant association with education.

Table 9: Frequency distribution of responses for Q.4 Who would you consult in case of an avulsed tooth?

\begin{tabular}{|c|c|c|c|c|c|}
\hline \multicolumn{2}{|c|}{} & Frequency & Percent & $\begin{array}{c}\text { Valid } \\
\text { Percent }\end{array}$ & $\begin{array}{c}\text { Cumulative } \\
\text { Percent }\end{array}$ \\
\hline Valid & Dentist & 470 & 93.3 & 93.3 & 93.3 \\
\cline { 2 - 6 } & Doctor & 30 & 6.0 & 6.0 & 99.2 \\
\cline { 2 - 6 } & $\begin{array}{c}\text { Family } \\
\text { member/ } \\
\text { Friend/ } \\
\text { Neighbor }\end{array}$ & 2 & .4 & .4 & 99.6 \\
\cline { 2 - 7 } & Other & 2 & .4 & .4 & 100.0 \\
\cline { 2 - 7 } & Total & 504 & 100.0 & 100.0 & \\
\hline
\end{tabular}

Table 10: Comparison of consultation in case of avulsed tooth and Education

\begin{tabular}{|c|c|c|c|c|c|}
\hline \multirow{2}{*}{} & & \multicolumn{5}{|c|}{ Who would you consult in case of an } \\
avulsed tooth?
\end{tabular}

\section{$* * * * \mathrm{p}$-value less than 0.05 indicates significant}

association.

Interpretation: Since p-value for the chi-square is less than that of 0.05 indicates significant association with education.

Table 11: Frequency distributions of responses for Q.6 Are you aware that you have to clean the dirty avulsed tooth?

\begin{tabular}{|c|l|r|r|r|r|}
\hline \multicolumn{2}{|c|}{} & Frequency & Percent & $\begin{array}{c}\text { Valid } \\
\text { Percent }\end{array}$ & $\begin{array}{c}\text { Cumulative } \\
\text { Percent }\end{array}$ \\
\hline \multirow{3}{*}{ Valid } & No & 182 & 36.1 & 36.1 & 36.1 \\
\cline { 2 - 6 } & Yes & 322 & 63.9 & 63.9 & 100.0 \\
\cline { 2 - 6 } & Total & 504 & 100.0 & 100.0 & \\
\hline
\end{tabular}

Table 12: Comparison of awareness about need to clean an avulsed tooth and Education:

\begin{tabular}{|c|c|c|c|}
\hline \multirow{2}{*}{} & & \multicolumn{2}{|c|}{$\begin{array}{c}\text { Are you aware that you have to } \\
\text { clean the dirty avulsed tooth? }\end{array}$} \\
\hline Education & & Yes & No \\
\hline Illiterate & Count & 23 & 5 \\
\hline \multirow{2}{*}{ Elementary school } & $\%$ & $82.10 \%$ & $17.90 \%$ \\
\cline { 2 - 4 } & Count & 93 & 46 \\
\cline { 2 - 4 } Higher secondary & Count & $66.90 \%$ & $33.10 \%$ \\
\cline { 2 - 4 } & $\%$ & $57.30 \%$ & $42.70 \%$ \\
\hline \multirow{2}{*}{ Graduate } & Count & 66 & 30 \\
\cline { 2 - 4 } & $\%$ & $68.80 \%$ & $31.20 \%$ \\
\hline \multirow{2}{*}{ Post graduate } & Count & 0 & $0.00 \%$ \\
\cline { 2 - 4 } & $\%$ & $0.00 \%$ & \multicolumn{3}{|c|}{3} \\
\hline \multicolumn{2}{|c|}{ Chi-square test value } & \multicolumn{3}{|c|}{0.021} \\
\hline \multicolumn{2}{|c|}{ Df } & & \multicolumn{3}{|c|}{} \\
\hline \multicolumn{2}{|c|}{ p-value } & \multicolumn{2}{|c|}{} \\
\hline
\end{tabular}




\section{International Journal of Science and Research (IJSR) \\ ISSN (Online): 2319-7064 \\ Index Copernicus Value (2013): 6.14 | Impact Factor (2014): 5.611}

****p-value less than 0.05 indicates significant association.

Interpretation: Since p-value for the chi-square is less than that of 0.05 indicates significant association with education.

Table 13: Frequency distributions of responses for Q.5 How would you clean the dirty avulsed tooth?

\begin{tabular}{|c|c|c|c|c|c|}
\hline \multicolumn{2}{|c|}{} & Frequency & Percent & $\begin{array}{c}\text { Valid } \\
\text { Percent }\end{array}$ & $\begin{array}{c}\text { Cumulative } \\
\text { Percent }\end{array}$ \\
\hline Valid & Brush & 126 & 25.0 & 25.0 & 25.0 \\
\cline { 2 - 6 } & Milk & 1 & .2 & .2 & 25.2 \\
\cline { 2 - 6 } & Nothing & 115 & 22.8 & 22.8 & 48.0 \\
\cline { 2 - 6 } & Salt water & 11 & 2.2 & 2.2 & 50.2 \\
\cline { 2 - 6 } & Water & 251 & 49.8 & 49.8 & 100.0 \\
\cline { 2 - 6 } & Total & 504 & 100.0 & 100.0 & \\
\hline
\end{tabular}

Table 14: Comparison of knowledge about how to clean an avulsed tooth and Education:

\begin{tabular}{|c|c|c|c|c|c|c|}
\hline \multirow{2}{*}{} & & \multicolumn{5}{|c|}{ How would you clean the dirty avulsed } \\
tooth?
\end{tabular}

**** p-value less than 0.05 indicates significant association.
Interpretation: Since p-value for the chi-square is less than that of 0.05 indicates significant association with education.

Table 15: Frequency distributions of responses for Q.7 How would you carry the tooth?

\begin{tabular}{|c|c|c|c|c|c|}
\hline \multicolumn{2}{|c|}{} & Frequency & Percent & $\begin{array}{c}\text { Valid } \\
\text { Percent }\end{array}$ & $\begin{array}{c}\text { Cumulative } \\
\text { Percent }\end{array}$ \\
\hline Valid & $\begin{array}{c}\text { Child's } \\
\text { mouth/saliva }\end{array}$ & 11 & 2.2 & 2.2 & 2.2 \\
\cline { 2 - 6 } & $\begin{array}{c}\text { Disinfecting } \\
\text { solution }\end{array}$ & 26 & 5.2 & 5.2 & 7.3 \\
\cline { 2 - 6 } & Fruit juice & 1 & .2 & .2 & 7.5 \\
\hline Ice water & 89 & 17.7 & 17.7 & 25.2 \\
\hline Milk & 5 & 1.0 & 1.0 & 26.2 \\
\hline & Saline solution & 25 & 5.0 & 5.0 & 31.2 \\
\cline { 2 - 6 } & $\begin{array}{c}\text { Wrap the tooth in } \\
\text { paper or } \\
\text { handkerchief }\end{array}$ & 347 & 68.8 & 68.8 & 100.0 \\
\cline { 2 - 6 } & Total & 504 & 100.0 & 100.0 & \\
\hline
\end{tabular}

Table 16: Comparison of knowledge of how to carry avulsed tooth and Education:

\begin{tabular}{|c|c|c|c|c|c|c|c|c|}
\hline & & \multicolumn{7}{|c|}{ How would you carry the tooth? } \\
\hline Education & & $\begin{array}{l}\text { Wrap the tooth in } \\
\text { paper or } \\
\text { handkerchief }\end{array}$ & Ice water & Milk & $\begin{array}{c}\text { Child's } \\
\text { mouth/saliva }\end{array}$ & $\begin{array}{l}\text { Disinfecting } \\
\text { solution }\end{array}$ & $\begin{array}{l}\text { Saline } \\
\text { solution }\end{array}$ & $\begin{array}{l}\text { Fruit } \\
\text { juice }\end{array}$ \\
\hline \multirow[t]{2}{*}{ Illiterate } & Count & 18 & 7 & 1 & 0 & 0 & 2 & 0 \\
\hline & $\%$ & $64.30 \%$ & $25.00 \%$ & $3.60 \%$ & $0.00 \%$ & $0.00 \%$ & $7.10 \%$ & $0.00 \%$ \\
\hline \multirow{2}{*}{$\begin{array}{c}\text { Elementary } \\
\text { school }\end{array}$} & Count & 107 & 24 & 0 & 1 & 4 & 3 & 1 \\
\hline & $\%$ & $76.40 \%$ & $17.10 \%$ & $0.00 \%$ & $0.70 \%$ & $2.90 \%$ & $2.10 \%$ & $0.70 \%$ \\
\hline \multirow{2}{*}{$\begin{array}{c}\text { Higher } \\
\text { secondary }\end{array}$} & Count & 164 & 37 & 2 & 4 & 11 & 7 & 0 \\
\hline & $\%$ & $72.90 \%$ & $16.40 \%$ & $0.90 \%$ & $1.80 \%$ & $4.90 \%$ & $3.10 \%$ & $0.00 \%$ \\
\hline \multirow{2}{*}{ Graduate } & Count & 56 & 17 & 2 & 3 & 8 & 10 & 0 \\
\hline & $\%$ & $58.30 \%$ & $17.70 \%$ & $2.10 \%$ & $3.10 \%$ & $8.30 \%$ & $10.40 \%$ & $0.00 \%$ \\
\hline \multirow{2}{*}{ Post graduate } & Count & 0 & 0 & 0 & 0 & 0 & 0 & 0 \\
\hline & $\%$ & $0.00 \%$ & $0.00 \%$ & $0.00 \%$ & $0.00 \%$ & $0.00 \%$ & $0.00 \%$ & $0.00 \%$ \\
\hline \multicolumn{2}{|c|}{ Chi-square test value } & \multicolumn{7}{|c|}{29.055} \\
\hline \multicolumn{2}{|l|}{ Df } & \multicolumn{7}{|c|}{18} \\
\hline \multicolumn{2}{|c|}{ p-value } & \multicolumn{7}{|c|}{0.048} \\
\hline
\end{tabular}

$* * * * \mathrm{p}$-value less than $\mathbf{0 . 0 5}$ indicates significant association.

Interpretation: Since p-value for the chi-square is less than that of 0.05 indicates significant association with education. 


\section{International Journal of Science and Research (IJSR) \\ ISSN (Online): 2319-7064 \\ Index Copernicus Value (2013): 6.14 | Impact Factor (2014): 5.611}

Table 17: Frequency distributions of responses for Q.8 Have you ever received any advice regarding emergency

\begin{tabular}{|c|c|c|c|c|c|}
\hline & & Frequency & Percent & $\begin{array}{c}\text { Valid } \\
\text { Percent }\end{array}$ & $\begin{array}{c}\text { Cumulative } \\
\text { Percent }\end{array}$ \\
\hline \multirow[t]{4}{*}{ Valid } & & 2 & .4 & .4 & .4 \\
\hline & No & 482 & 95.6 & 95.6 & 96.0 \\
\hline & Yes & 20 & 4.0 & 4.0 & 100.0 \\
\hline & Total & 504 & 100.0 & 100.0 & \\
\hline
\end{tabular}

Table 18: Comparison of receiving any advise regarding emergency management of avulsed tooth and Education:

\begin{tabular}{|c|c|c|c|}
\hline & & \multicolumn{2}{|c|}{$\begin{array}{l}\text { Have you ever received any } \\
\text { advice regarding emergency } \\
\text { management of avulsed tooth? }\end{array}$} \\
\hline Education & & Yes & No \\
\hline \multirow[t]{2}{*}{ Illiterate } & Count & 2 & 26 \\
\hline & $\%$ & $7.10 \%$ & $92.90 \%$ \\
\hline \multirow{2}{*}{$\begin{array}{c}\text { Elementary } \\
\text { school }\end{array}$} & Count & 4 & 136 \\
\hline & $\%$ & $2.90 \%$ & $97.10 \%$ \\
\hline \multirow{2}{*}{$\begin{array}{c}\text { Higher } \\
\text { secondary }\end{array}$} & Count & 5 & 219 \\
\hline & $\%$ & $2.20 \%$ & $97.80 \%$ \\
\hline \multirow{2}{*}{ Graduate } & Count & 6 & 89 \\
\hline & $\%$ & $6.30 \%$ & $93.70 \%$ \\
\hline \multirow{2}{*}{$\begin{array}{c}\text { Post } \\
\text { graduate }\end{array}$} & Count & 0 & 0 \\
\hline & $\%$ & $0.00 \%$ & $0.00 \%$ \\
\hline \multicolumn{2}{|c|}{ Chi-square test value } & \multicolumn{2}{|c|}{4.579} \\
\hline \multicolumn{2}{|c|}{ Df } & \multicolumn{2}{|c|}{3} \\
\hline \multicolumn{2}{|c|}{$p$-value } & \multicolumn{2}{|c|}{0.205} \\
\hline
\end{tabular}

\section{$* * * * \mathbf{p}$-value less than 0.05 indicates significant} association.

Interpretation: Since p-value for the chi-square is greater than that of 0.05 indicates no significant association with education.

Table 19: Frequency distributions of responses for Q.11 Do you agree to the importance of saving the avulsed tooth?

\begin{tabular}{|c|c|c|c|c|c|}
\hline \multicolumn{2}{|c|}{} & Frequency & Percent & $\begin{array}{c}\text { Valid } \\
\text { Percent }\end{array}$ & $\begin{array}{c}\text { Cumulative } \\
\text { Percent }\end{array}$ \\
\hline \multirow{3}{*}{ Valid } & No & 22 & 4.4 & 4.4 & 4.4 \\
\cline { 2 - 6 } & Yes & 482 & 95.6 & 95.6 & 100.0 \\
\cline { 2 - 6 } & Total & 504 & 100.0 & 100.0 & \\
\hline
\end{tabular}

Table 20: Comparison of agreement to importance of saving avulsed tooth and Education:

\begin{tabular}{|c|c|c|c|}
\hline & & \multicolumn{2}{|c|}{$\begin{array}{c}\text { Do you agree to the importance } \\
\text { of saving the avulsed tooth? }\end{array}$} \\
\hline Education & & Yes & No \\
\hline \multirow[t]{2}{*}{ Illiterate } & Count & 25 & 2 \\
\hline & $\%$ & $92.60 \%$ & $7.40 \%$ \\
\hline \multirow{2}{*}{ Elementary school } & Count & 128 & 12 \\
\hline & $\%$ & $91.40 \%$ & $8.60 \%$ \\
\hline \multirow{2}{*}{ Higher secondary } & Count & 218 & 7 \\
\hline & $\%$ & $96.90 \%$ & $3.10 \%$ \\
\hline \multirow{2}{*}{ Graduate } & Count & 95 & 1 \\
\hline & $\%$ & $99.00 \%$ & $1.00 \%$ \\
\hline \multirow{2}{*}{ Post graduate } & Count & 0 & 0 \\
\hline & $\%$ & $0.00 \%$ & $0.00 \%$ \\
\hline \multicolumn{2}{|c|}{ Chi-square test value } & \multicolumn{2}{|c|}{9.596} \\
\hline \multicolumn{2}{|l|}{$\overline{\mathrm{Df}}$} & \multicolumn{2}{|c|}{3} \\
\hline \multicolumn{2}{|l|}{$p$-value } & \multicolumn{2}{|c|}{0.022} \\
\hline
\end{tabular}

$* * * * \mathrm{p}$-value less than 0.05 indicates significant association.

Interpretation: Since p-value for the chi-square is less than that of 0.05 indicates significant association with education.
Table 21: Frequency distributions of responses for Q.12 Do you have previous experience of managing dental

\begin{tabular}{|l|l|r|r|r|r|}
\hline \multicolumn{2}{|c|}{} & & & $\begin{array}{c}\text { Valid } \\
\text { Frequency }\end{array}$ & $\begin{array}{c}\text { Cumulative } \\
\text { Percent }\end{array}$ \\
Percent & Percent \\
\hline \multirow{3}{*}{ Valid } & No & 469 & 93.1 & 93.1 & 93.1 \\
\cline { 2 - 6 } & Yes & 35 & 6.9 & 6.9 & 100.0 \\
\cline { 2 - 6 } & Total & 504 & 100.0 & 100.0 & \\
\hline
\end{tabular}

Table 22: Frequency distributions of responses for Q.13 Do you have any previous experience of dental trauma (broken, avulsed, and other)?

\begin{tabular}{|c|l|r|r|r|r|}
\hline \multicolumn{2}{|c|}{} & Frequency & Percent & $\begin{array}{c}\text { Valid } \\
\text { Percent }\end{array}$ & $\begin{array}{c}\text { Cumulative } \\
\text { Percent }\end{array}$ \\
\hline \multirow{3}{*}{ Valid } & No & 393 & 78.0 & 78.0 & 78.0 \\
\cline { 2 - 6 } & Yes & 111 & 22.0 & 22.0 & 100.0 \\
\cline { 2 - 6 } & Total & 504 & 100.0 & 100.0 & \\
\hline
\end{tabular}

Table 23: Frequency distributions of responses for Q.10 Are you interested in receiving more information about the emergency management of avulsed tooth?

\begin{tabular}{|c|c|c|c|c|c|}
\hline & Frequency & Percent & $\begin{array}{c}\text { Valid } \\
\text { Percent }\end{array}$ & $\begin{array}{c}\text { Cumulative } \\
\text { Percent }\end{array}$ \\
\hline \multirow[t]{4}{*}{ Valid } & & 1 & .2 & .2 & .2 \\
\hline & No & 15 & 3.0 & 3.0 & 3.2 \\
\hline & Yes & 488 & 96.8 & 96.8 & 100.0 \\
\hline & Total & 504 & 100.0 & 100.0 & \\
\hline
\end{tabular}

Table 24: Comparison of interest in receiving more information about the emergency management of avulsed tooth and Education

\begin{tabular}{|c|c|c|c|}
\hline & & \multicolumn{2}{|c|}{$\begin{array}{l}\text { Are you interested in receiving more } \\
\text { information about the emergency } \\
\text { management of avulsed tooth? }\end{array}$} \\
\hline Education & & Yes & No \\
\hline \multirow[t]{2}{*}{ Illiterate } & Count & 24 & 4 \\
\hline & $\%$ & $85.70 \%$ & $14.30 \%$ \\
\hline \multirow{2}{*}{$\begin{array}{c}\text { Elementary } \\
\text { school }\end{array}$} & Count & 131 & 8 \\
\hline & $\%$ & $94.20 \%$ & $5.80 \%$ \\
\hline \multirow{2}{*}{$\begin{array}{c}\text { Higher } \\
\text { secondary }\end{array}$} & Count & 222 & 2 \\
\hline & $\%$ & $99.10 \%$ & $0.90 \%$ \\
\hline \multirow{2}{*}{ Graduate } & Count & 94 & 1 \\
\hline & $\%$ & $98.90 \%$ & $1.10 \%$ \\
\hline \multirow{2}{*}{ Post graduate } & Count & 0 & 0 \\
\hline & $\%$ & $0.00 \%$ & $0.00 \%$ \\
\hline \multicolumn{2}{|c|}{ Chi-square test value } & \multicolumn{2}{|c|}{19.968} \\
\hline \multicolumn{2}{|l|}{ Df } & \multicolumn{2}{|c|}{3} \\
\hline \multicolumn{2}{|c|}{$p$-value } & \multicolumn{2}{|c|}{0.000} \\
\hline
\end{tabular}

\section{$* * * * \mathrm{p}$-value less than 0.05 indicates significant} association.

Interpretation: Since p-value for the chi-square is less than that of 0.05 indicates significant association with education.

\section{Legend of Tables}

Table 1: Questionnaire

Table 2: Demographic data

Table 3: Frequency distribution of responses for Q.1 Are you aware of possibility of re-implantation of avulsed tooth as part of first-aid in treatment modality?

Table 4: Comparison of awareness of possibility of reimplantation of avulsed tooth as part of first-aid in treatment modality and Education and Gender: 


\section{International Journal of Science and Research (IJSR) \\ ISSN (Online): 2319-7064 \\ Index Copernicus Value (2013): 6.14 | Impact Factor (2014): 5.611}

Table 5: Frequency distribution of responses for Q.2 How soon do you believe re-implantation of avulsed tooth should be done?

Table 6: Comparison of belief of promptness of reimplantation of avulsed tooth and Education.

Table 7: Frequency distribution of responses for Q.3 Would you attempt to self re-implant the tooth?

Table 8: Comparison of attempt to self re-implant the tooth and Education.

Table 9: Frequency distribution of responses for Q.4 Who would you consult in case of an avulsed tooth?

Table 10: Comparison of consultation in case of avulsed tooth and Education.

Table 11: Frequency distributions of responses for Q.6 Are you aware that you have to clean the dirty avulsed tooth?

Table 12: Comparison of awareness about need to clean an avulsed tooth and Education:

Table 13: Frequency distributions of responses for Q.5 How would you clean the dirty avulsed tooth?

Table 14: Comparison of knowledge about how to clean an avulsed tooth and Education:

Table 15: Frequency distributions of responses for Q.7 How would you carry the tooth?

Table 16: Comparison of knowledge of how to carry avulsed tooth and Education:

Table 17: Frequency distributions of responses for Q.8 Have you ever received any advice regarding emergency management of avulsed tooth?

Table 18: Comparison of receiving any advise regarding emergency management of avulsed tooth and Education:

Table 19: Frequency distributions of responses for Q.11 Do you agree to the importance of saving the avulsed tooth?

Table 20: Comparison of agreement to importance of saving avulsed tooth and Education

Table 21: Frequency distributions of responses for Q.12 Do you have previous experience of managing dental avulsion? Table 22: Frequency distributions of responses for Q.13 Do you have any previous experience of dental trauma (broken, avulsed, and other) ?

Table 23: Frequency distributions of responses for Q.10 Are you interested in receiving more information about the emergency management of avulsed tooth?

Table 24: Comparison of interest in receiving more information about the emergency management of avulsed tooth and Education:

\section{Discussion}

People themselves can play an important role in improving the prognosis of the avulsed tooth, if they are aware of possibility of reimplanation of avulsed tooth. This not only saves the tooth but also protects the psychological integrity and aesthetic harmony. According to Abeer $\mathrm{M}$ et al, a child shows lower self esteem when the aesthetic harmony is insulted by dental trauma ${ }^{[14]}$. The dental trauma can get impregnated in their mind which can form a paradigm that dental treatments are always related to pain. This leads to dental anxiety and apprehension and so a patient avoids dental checkups and treatments.

The present study was designed for patients visiting a dental hospital in metropolitan city because it is quite economical and easily accessible for majority of patients. Also, the city houses people who have migrated from different cities all over India and so this allows us to survey a diverse section of people. A questionnaire (Table 1) containing set of 13 questions on knowledge and awareness of managing dental avulsion was prepared and a pilot study was conducted to see the reliability and validity of our study. A sample size of 504 patients was surveyed individually so that every patient understood the questions as well as got properly educated.

An avulsed permanent tooth can be re-implanted and so should be retrieved immediately. This not only saves the viability of the tooth but also saves the patient from aspirating the tooth. As per our survey, majority of participants (94.8\%) were unaware of possibility of reimplantation of the avulsed tooth (Table 3) but this was independent of gender and education( $(p>0.05)$ (Table 4) . This was in agreement with previous studies conducted including Toure et al in Morocco, Lin et al in Hong Kong, Sanu O.O et al in Nigeria, Sae-Lim V et al Singapore and P. Prathyush et al in Bangalore where majority of participants were unaware of re-implantation of avulsed tooth ${ }^{[15-19]}$.

About $48 \%$ of the respondents agreed to the importance of re-implantation immediately with majority of the graduates in our study following the same notion (Table 5) and since p-value for the chi-square is less than that of 0.05 , it indicates significant association with education (Table 6). When asked if they would self implant the tooth, $87.8 \%$ of the female respondents and $82 \%$ of the participants unaware of possibility of re-implantation, disagreed to it (Table 7) and Since p-value for the chi-square is less than that of 0.05 , it indicates significant association with education (Table 8) . This was in line with previous studies conducted where very few respondents agree to self re-implanting the tooth ${ }^{[20-26]}$. Raphael and Gregory had a contradicting result as 2/3 of the respondents in their study would self re-implant the tooth ${ }^{[9]}$.

There is always anxiety compounded with need of the emergency treatment involved for patients who face dental trauma. Despite the disquietude, 93.2\% male and 93.4\% female respondents said that they would consult a dentist for the treatment (Table 9) and since p-value for the chi-square is less than that of 0.05 , it indicates significant association with education (Table 10). Amongst the respondents who were unaware of possibility of re-implantation following dental avulsion, 93.5\% said they would visit a dentist in such an emergency. This is in agreement with previous studies conducted [10, 26]. It was contradicting to a study conducted by Shashikiran et al ${ }^{[22]}$, where they reported that most rural parents would send their child to a doctor because of lack of dental clinics. This could be associated with education level as $99 \%$ graduates in our study would see a dentist. This could also be due to the fact that respondents in our study are the ones visiting a dental institute.

It is necessary to carefully clean the dirty avulsed tooth with an appropriate cleaning medium without damaging the viability of periodontal ligaments. Only few respondents in other studies conducted, knew the correct cleaning media to be used $[14,20,23,24]$. In the present study, $82.1 \%$ of the illiterate and $92.3 \%$ of the respondents who were aware of possibility of re-implantation agreed that dirty avulsed tooth had to be cleaned before implantation (Table 11) and since 


\section{International Journal of Science and Research (IJSR) \\ ISSN (Online): 2319-7064 \\ Index Copernicus Value (2013): 6.14 | Impact Factor (2014): 5.611}

$\mathrm{p}$-value for the chi-square is less than that of 0.05 indicates significant association with education (Table 12).

But there was lack of knowledge about the need for cleaning the avulsed tooth and the correct cleaning method to be used (Table 13). About $63.2 \%$ graduates and $53.8 \%$ of total respondents who were aware of possible re-implantation would use water as cleaning medium and $35.7 \%$ from the category chose to use toothbrush to clean the dirty avulsed tooth. Since p-value for the chi-square is less than that of 0.05 , it indicates significant association with education (Table 14).

Cleaning with a toothbrush would damage the viable cells of the periodontal ligament which are capable of regeneration. An ideal storage medium will not only preserve the vitality of periodontal cells but also is easily accessible and available at the accident site ${ }^{[27]}$. Many previous studies ${ }^{[9,10,}$ $\left.{ }^{19}, 26\right]$ have demonstrated that there is lack of knowledge about the correct storage medium. In our survey, a mere $0.6 \%$ respondents aware of possible re-implantation, chose milk as storage media and about $1 \%$ chose child's saliva to be appropriate (Table 15) Since p-value for the chi-square is less than that of 0.05 , it indicates significant association with education (Table 16).

The majority of male respondents chose to use dry storage as appropriate medium to carry the avulsed tooth. In fact, level of education showed no difference as $64.3 \%$ illiterate, $72.9 \%$ higher secondary and $58.3 \%$ graduate chose dry storage by wrapping the tooth in a handkerchief or paper as the right option. It was worrisome to see $17.7 \%$ respondents chose ice water as the appropriate storage medium. We believe that the choice of selecting a transport medium is based on the ease of availability and hence using cold water or wrapping the tooth in handkerchief or paper is done. One must know that most easily available and suitable storage media are milk, coconut water or child's own saliva. Milk is considered to be most desirable with optimum $\mathrm{pH}$ and osmolarity ${ }^{[28-30]}$. Thomas et al showed that tender coconut water is as effective as Hank's Balanced Salt Solution (HBSS) during extra-oral duration of 15-120 minutes ${ }^{[2]}$.

There is lack of awareness of emergency management of saving the avulsed tooth which can be seen clearly as even the $93.7 \%$ graduates never received any information regarding emergency management of avulsed tooth (Table 17) but since p-value for the chi-square is greater than that of 0.05 indicates no significant association with education (Table 18). It was good to see that $95.8 \%$ of respondents who were unaware of possible re-implantation and $92.6 \%$ of the illiterate respondents agreed to the importance of saving avulsed tooth (Table 19) and there was a significant association with education (Table 20).

Majority of respondents irrespective of level of education or gender said they have never had a previous experience of managing dental avulsion (Table 21 and 22). But about $57.7 \%$ of the respondents aware of possible re-implantation believed to have managed previous dental avulsion. Very few of the respondents had any previous experience of dental trauma with $38.5 \%$ of people aware of possible reimplantation had previous experience of dental trauma.
It was very encouraging to see that $85.7 \%$ of illiterate respondents and $99 \%$ graduate respondents were interested in receiving more information regarding the management of avulsed tooth (Table 23) and there was a significant association with education $(\mathrm{p}<0.05)$ (Table 24$)$. Most of the respondents actively discussed their queries at the end of the survey and were very keen to hear the correct approach for the same.

\section{Conclusions}

Within the confines and limitation of the present study, it was concluded that irrespective of education level, gender or awareness level about possible re-implantation of avulsed tooth, there is a generalised lack of awareness about the emergency management of avulsed tooth even in a big metropolitan Indian city. The importance of saving the natural teeth has faded away because of variety of available prosthesis, but nothing can truly replace what is created by nature . There is a need for dental professionals and civic authorities to spread awareness so that people can not only fearlessly enjoy their childhood but also grow up as confident men and pass on the gene of correct knowledge. The awareness regarding re-implantation will not only save time but also save money for people in the country.

\section{References}

[1] Andreasen JO, Ravn JJ. Epidemiology of traumatic dental injuries to primary and permanent teeth in a Danish population sample. Int J Oral Surg. 1972;1:2359.

[2] Thomas T, Gopikrishna V, Kandaswamy D. Comparative evaluation of maintenance of cell viability of an experimental transport media "coconut water" with Hank's balanced salt solution and milk, for transportation of an avulsed tooth: An in vitro cell culture study. J Conserv Dent 2008;11:22-9.

[3] Govindarajan M, Reddy VN, Ramalingam K, Durai KS, Rao PA, Prabhu A. Prevalence of traumatic dental injuries to the anterior teeth among three to thirteenyear-old school children of Tamilnadu. Contemp Clin Dent 2012;3:164-7.

[4] Ankola AV, Hebbal M, Sharma R, Nayak SS. Traumatic dental injuries in primary school children of South India - a report from district-wide oral health survey. Dent Traumatol 2012;29:134-8

[5] Andreasen JO, Borum MK, Jacobsen HL, Andreasen FM. Reimplantation of 400 avulsed permanent incisors. 1. Diagnosis of healing complications. Endod Dent Traumatol 1995;11:51-8.

[6] Nuket S, Sule C, Nurhan G. Clinical investigation of traumatic injuries in Yeditepe University, Turkey during the last 3 years. Dent Traumatolo 2005;21:4:18894

[7] Petti S, Tarsitani G. Traumatic injuries to anterior teeth in Italian schoolchildren: prevalence and risk factors. Dental Traumatology 1996;12:6:294-97.

[8] Grossman's Endodontic Practice, $12^{\text {th }}$ edition, Chapter 15 Treatment of Traumatized Teeth, Pg378, Avulsion.

[9] Raphael SL ${ }^{1}$, Gregory PJ. Parental awareness of the emergency management of avulsed teeth in children. Aust Dent J. 1990 Apr;35(2):130-3.

\section{Volume 5 Issue 3, March 2016}




\section{International Journal of Science and Research (IJSR) \\ ISSN (Online): 2319-7064 \\ Index Copernicus Value (2013): 6.14 | Impact Factor (2014): 5.611}

[10] Ozer S, Yilmaz EI, Bayrak S, Tunc ES. Parental knowledge and attitudes regarding the emergency treatment of avulsed permanent teeth. Euro J Dent 2012;6:370-5.

[11] Panzarini, S. R., Pedrini, D., Brandini, D. A., Poi, W. R., Santos, M. F., Correa, J. P. T. and Silva, F. F. (2005), Physical education undergraduates and dental trauma knowledge. Dental Traumatology, 21: 324-328. doi: 10.1111/j.1600-9657.2005.00327.x

[12] Subhashraj, K. (2009), Awareness of management of dental trauma among medical professionals in Pondicherry, India. Dental Traumatology, 25: 92-94. doi: 10.1111/j.1600-9657.2008.00714.x

[13] Sae-Lim, V., Chulaluk, K. and Lim, L. P. (1999), Patient and parental awareness of the importance of immediate management of traumatised teeth. Dental Traumatology, 15: 37-41. doi: 10.1111/j.16009657.1999.tb00747.x

[14] Abeer M, Abdellatif, Salwa A. Hegazy: Knowledge of emergency management of avulsed teeth among a sample of Egyptian parents. J Advanced Res 2011;2:157-62.

[15] Touré B, Benoist FL, Faye B, Kane A, Kaadioui S. Primary school teachers' knowledge regarding emergency management of avulsed permanent incisors. J Dent (Tehran) 2011;8:117-22.

[16] Lin S, Levin L, Emodi O, Fuss Z, Peled M. Physician and emergency medical technicians' knowledge and experience regarding dental trauma. Dent Traumatol. 2006;22(3):124-6

[17] Sanu OO, Utomi IL. Parenteral awareness of emergency management of avulsion of permanent teeth of children in Lagos, Nigeria. Niger Postgrad Med J. 2005;12:115120.

[18] Sae-Lim V, Chulaluk K, Lim LP. Patient and parental awareness of the importance of immediate management of traumatized teeth. Endod Dent Traumatol. 1999;15:37-41

[19] Prathyusha P, Harshini T, Haripriya B, Pramod IJ, Swathi K, Samyuktha CL. Knowledge and Awareness Regarding Avulsion and Its Immediate Treatment in School Teachers in Bangalore City (South). Journal of International Oral Health : JIOH. 2015;7(8):93-97.

[20] Ozer S, Yilmaz EI, Bayrak S, Tunc ES. Parental knowledge and attitudes regarding the emergency treatment of avulsed permanent teeth. European Journal of Dentistry. 2012;6(4):370-375.

[21] Andersson L, Al-Asfour A, Al-Jane Q. Knowledge of first-aid measures of avulsion and replantation of teeth: an interview of 221 Kuwaiti schoolchildren. Dent Traumatol. 2006;22:57-65.

[22] Shashikiran ND, Reddy VV, Nagaveni NB. Knowledge and attitude of 2,000 parents (urban and rural - 1000 each) with regard to avulsed permanent incisors and their emergency management, in and around Davangere. J Indian Soc Pedod Prev Dent 2006;24:11621.

[23] Al-Jame Q, Andersson L, Al-Asfour A. Kuwaiti parents' knowledge of first-aid measures of avulsion and replantation of teeth. Med Princ Pract 2007;16:274-9

[24] Santos ME, Habecost AP, Gomes FV, Weber JB, de Oliveira MG. Parent and caretaker knowledge about avulsion of permanent teeth. Dent Traumatol 2009;25:203-8.

[25] Ayodele A, Elizabeth O, Vincent U, Akinwale A. Knowledge of first aid measrures of avulsion and replantation of teeth in Nigerian school children. Internet J Dent Sci 2009;7.

[26]Deepa Gurunathan ${ }^{1}$, Tee Jing Loo $^{2}$, Sujatha Somasundaram ${ }^{3}$ Knowledge and attitude of parents with regard to avulsed permanent tooth of their children and their emergency management-Chennai Journal of Indian Society of Pedodontics and Preventive Dentistry, Vol. 32, No. 2, April-June, 2014, pp. 97-107

[27] Ashkenazi M, Marouni M, Sarnat H. In vitro viability, mitogenicity and clonogenic capacity of periodontal ligament cells after storage in four media at room temperature. Endod Dent Traumatol.2000;16:63-70

[28] Trope M. Clinical management of the avulsed tooth: Present strategies and future directions. Dent Traumatol. 2002;18(1):1-11

[29] American Academy of Pediatric Dentistry- Decision Tree for Management of Avulsed Permanent Tooth

[30]Blomlöf L. Milk and saliva as possible storage media for traumatically exarticulated teeth prior to replantation. Swed Dent J Suppl 1981;8:1-26. 